\title{
Impact of Fathers Involvement on Childhood Health and Development in Ikot Abasi of Akwa Ibom State
}

\author{
${ }^{1}$ Ukeme E. Eyo, ${ }^{2}$ N.F. Iko \\ ${ }^{l}$ Department of Physical and Health Education Faculty of Education, University Of Uyo, Akwa Ibom State, \\ Nigeria \\ ${ }^{2}$ Department of Early Childhood Education, Faculty of Education, University Of Uyo, Akwa Ibom State, Nigeria
}

\begin{abstract}
The study was carried out to assess the impact of father's involvement on child's health and development. Father's involvement is reasonably important for a child's health and development. One hundred (100) teachers in Secondary schools in Ikot Abasi Local Government Area were selected through stratified random sampling. Four null hypotheses were formulated and tested at .05 alpha level. Chi-square and one-way analysis of variance statistical methods were adopted for testing the hypotheses. The design for the study was a descriptive design method. The findings reveled that: Fatherly roles (direct or indirect) impact significantly on child's health outcomes. Father's caring attitudes affect positively the child's academic performances. Father's educational levels significantly influence on child's health and development. Finally, father's socio-economic status has positive influence on child's health development. It was recommended that fathers influence should be well established in the family.
\end{abstract}

Keywords: Fathers Involvement, Childhood Health, Development

\section{Introduction}

In the last decade, social sciences have begun recognizing examining the crucial roles that fathers play child development and family dynamics. Societal and economic shifts have expanded the roles that fathers play in their families. Father involvement is associated with positive cognitive, developmental, and socio behavior, such as improved weight gain in preterm infants, improved breastfeeding rates, higher receptive language skills, and higher academic achievement. Comprehensive involvement of father is ideal for the child's well-being and health. There is no denying of the importance of and positive influence a father's active involvement plays in his child's development (Public Health Agency of Canada, 2003).

The fatherhood research has increased dramatically during recent decades and has also become a multidisciplinary scientific field of knowledge. Behind this development there are several major changes in modern society, such as shifting marriage and divorce patterns, increasing labour force participation of women and the growth and of the women's movement with its focus on gender equality and increased men's involvement in family. The result is that the research literature has raised many questions about men's parenting, reflecting positive as well as problematic aspects. The challenging and difficult side of men's parenting has mostly been framed in discussions about "deadbeat dads" or "feckless fathers" that ignore their parenting responsibilities. Fathers' shortcomings in taking equal responsibility for the internal family work and how this negatively affects women's opportunities to combine work and family life is another example of problematic behavior that has been discussed. Men and fathers have also been discussed in connection with domestic violence and other destructive that negatively affect their health and that of their family (Barlett, 2004).

\subsection{Problems of the Study}

For many years research on children's development and well-being has been focusing on the dynamics between mothers and their children (Bowlby, 1982). Fathers were often assumed to on the periphery of children's lives and, so, of little direct importance to children's development (Lamb, 1997). To underestimate the role of a father in a child development and well-being is especially unfortunate, give that there are several reasons why one should expect fathers to be particularly significant in children's health outcomes. This study would look on the impacts that father's involvement would have on child's health and development outcomes.

\subsection{Objectives of the study}

The study was carried out specifically to:

1. examine the fatherly role in child's health outcomes.

2. assess how fatherly caring attitudes affect child's academic performance

3. discover how the father's educational level influence child's health and development

4. ascertain the influence of father's socio-economic status on child's health outcome and development. 
1.3 Research Hypotheses

The following null hypotheses were tested in the study:

1. Fatherly roles do not significantly affect child's health outcomes

2. Father's caring attitudes do not significantly affect child academic performance

3. There is no significant influence of father's educational levels on child's health and development

4. Father's socio-economic status does not significantly influence child's health and development.

\section{Method}

\subsection{Research Design}

The design for the study was a descriptive survey study, where the subjects for the study were required to respond to the items on the questionnaire. It survey nature was precipitated by the fact that the research were concerned with describing the existence of event with no intention to manipulate any variable(s) that is associated with the study.

\subsection{Research Area}

This study was carried out in the urban area of Ikot Abasi Local Government Area of Akwa Ibom State.

\subsection{Population of the study}

The population for the study was all the teachers teaching in both public and private secondary schools in the urban area. The total population consisted of about two hundred and three (203) teachers, consisting of males and females.

\subsection{Sample and sampling techniques}

A stratified random sampling procedure was adopted in order to effectively represent the subjects. Stratified random sampling is a type of probability random sampling, where the researcher is interested is particular strata within the population (e.g, males vs. females). The choice of this type of sampling techniques in this study is unique as the researchers were interested in obtaining responses from both sexes to arrive at a good conclusion.

\subsection{Sample and sampling technique}

One hundred (100) teachers were randomly drawn from the population of 203teachers from ten public and privates secondary schools in Ikot Abasi Uruan Area to constitute the subject for the study.

\subsection{Reliability}

A pilot study was carried out in one of the secondary schools in the population area. A split-half reliability was done. Spearman-Brown Prophesy estimates were used to measure the internal stability of the instrument of the items constituting the variables of the study. The reliability coefficient obtained was .76.

\subsection{Techniques for data analysis}

The data analysis procedure for this study was through descriptive statistics for analysis of demographic data, chi-square and analysis of variance (ANOVA) methods.

\section{Results}

Results are presented and interpreted according to data analyses. In Table one, 30 subjects who were holders of OND/NCE, representing 30\%. Forty two First degree holders (42\%); Post graduate holders (28\%). In Table 2 out of the one hundred subjects for the study, married (men \& women) were $5(5 \%)$. The hypotheses were tested at .05 significance level, using chi-square method of analysis.

\subsection{Hypothesis one:}

Fatherly roles do not significantly impact on child's health outcomes. This hypothesis was tested at .05 significance level, using chi-square method of analysis.

\subsection{Hypothesis two}

Father's caring attitudes do not affect a child's academic performances.

\subsection{Hypothesis three}

There is no significant influence of father's education level on child's health and development. 


\subsection{Hypothesis four}

Father's socio-economic status does not significantly influence a child's health and development.

\subsection{Hypothesis I}

\section{Discussion}

The findings revealed that calculated chi-square of 11.63 is greater than the critical or table value of 7.83 at .05 significance level with 3 degrees of freedom, showing that, fatherly roles do significantly impact on child's health outcomes. Meaning that the father's roles whether direct or indirect helps to improve the child's health conditions. This finding agree with Gjerdingen, Froberg, and Fontaine, (1991) that fathers can directly and indirectly influence the physical health and well-being of their children through facilitating optimal health outcomes for mothers.

\subsection{Hypothesis2}

The result showed that, father's caring attitudes significantly affect a child's academic performances. Is in agreement with a study carried out by National Center for Education Statistics (1997) that children of involved and caring fathers are more likely to enjoy school, have attitudes toward school, participate in extracurricular activities, and graduate. They are also less likely to fail a grade, have poor attendance, or have behavior problems at school.

\subsection{Hypothesis 3}

The result showed that the higher the father's level of education, the significant improvement in child's health and development outcomes. This finding agrees with the research carried out by Bradley and Corwyn (2002) and Zvara (2009) that father's education level is an important factor in predicating children's development and health outcomes.

\subsection{Hypothesis 4}

The result showed that the higher the father's socio-economic status, there is a significant possible improvement in child's health and development outcomes. Child's heath and development outcomes are mostly due to the father's level of income and occupation as his continuous contributions, on average more than $50 \%$ of the family income (Amato \& Booth, 1997).

\section{Conclusion}

Based on the results obtained from the study, it is very necessary for fathers to be involved in the health and development of their children, showing great concern, and provide the needed assistance to the wives. Fathers should be the most important persons in the lives of their children for proper and better health and development, academically as well as all round aspects of life.

\section{Recommendations}

Based on the findings, the following recommendations were made:

- That the fathers should establish his influence on the child.

- That the fathers should show themselves as the first to reckon with in order to build the child's confidence on him;

- That the fathers should ensure that they interact with the children, be loving and caring;

- Fathers and would be fathers should endeavor to try to reach higher educational and socio-economic status for the better health and development of their children.

Table 1: Respondents by educational qualifications

\begin{tabular}{lll}
\hline Qualifications & Frequency & Percentage \\
\hline & & \\
OND/NCE & 30 & 30 \\
FIRST DEGREE & 42 & 42 \\
POST GRADUATE & 28 & 28 \\
TOTAL & 100 & 100 \\
\hline
\end{tabular}

In Table one, 30 subjects who were holders of OND/NCE, representing 30\%. Forty two First degree holders (42\%); Post graduate holders (28\%). 
Table 2: Respondents by marital status

\begin{tabular}{lll}
\hline Marital status & Frequency & Percentage \\
\hline Married & 86 & 86 \\
Divorced & 9 & 9 \\
Widow & 5 & 5 \\
Total & 100 & 100 \\
\hline
\end{tabular}

In Table 2 out of the one hundred subjects for the study, married (men \& women) were $5(5 \%)$.

Table 3: showing the observed and expected frequencies of the respondents

\begin{tabular}{llllllll}
\hline $\begin{array}{l}\text { Fatherly } \\
\text { roles: }\end{array}$ & SA & A & D & SD & Total & Cal. $x^{2}$. & Crit. $^{2}$ \\
\hline & & & & & & & \\
Direct & $20(27.0)$ & $13(13.5) 20(13.5)$ & $1(.54)$ & & 54 & & \\
Indirect & $30(23.0)$ & $12(1.5)$ & $5(11.5)$ & $0(.46)$ & 46 & & \\
Total & 50 & 25 & 25 & 1 & 100 & 11.63 & 7.83 \\
\hline
\end{tabular}

Table 3 shows the calculated chi-square of 11.63 is greater than the critical or Table value of 7.83 at .05 significance level with 3 degrees of freedom. This result signifies that null hypothesis is rejected in favour of the alternative hypothesis: That, fatherly roles do significantly impact on child's health outcomes. Meaning that the father's roles whether direct or indirect helps to improve the child's health conditions.

Table 4: Showing the observed and expected frequencies of the respondents.

\begin{tabular}{|c|c|c|c|c|c|c|c|}
\hline $\begin{array}{l}\text { Fatherly } \\
\text { roles: }\end{array}$ & $\overline{\text { SA }}$ & $\overline{\mathrm{A}}$ & $\mathrm{D}$ & SD & Total & Cal.x ${ }^{2}$ & $\overline{\text { Crit. } \mathrm{x}^{2}}$ \\
\hline Direct & $21(27.0)$ & $12(11.5)$ & $20(12.42)$ & $1(1.08)$ & 54 & & \\
\hline Indirect & $29(23.0)$ & $12(13.5)$ & $3(10.58)$ & $1(0.29)$ & 46 & & \\
\hline Total & 50 & 25 & 23 & 2 & 100 & 12.69 & 7.83 \\
\hline
\end{tabular}

Table 4 shows the calculated chi-square of 12.69 is greater than the critical or table value of 7.8305 significance level with 3 degrees of freedom. This result signifies that the null hypothesis is rejected in favour of the alternative hypothesis: That, father's caring attitudes significantly affect a child's academic performances. Meaning that when a father is always caring, there is the possibility that the child will perform better academically.

Table 5: Result of one way analysis of variance of the influence of father's educational level on child's health and development

\begin{tabular}{llllll}
\hline Variance sources & Sum of square (SS) & Degrees of freedom & Mean of square & F-Cal. & F-Crit. \\
\hline & & & & & \\
Between & 11.19 & 2 & 5.59 & 8.73 & 3.09 \\
Within & 62.32 & 97 & 64 & & \\
Total & 73.51 & 99 & & & \\
\hline
\end{tabular}

The result of one-way analysis of variance in Table 5shows that there is significant influence of father's educational level on child's heath and development. F $(2,97)=8.73,05$. The Least Significance difference (LSD) comparison $\mathrm{s}$ revealed that all the free means were significantly different from others. High educational level with the $(M=2.91)$ than the mean of middle level of education $(M=2.24)$, and lower level of education wit $(M=2.12)$. The result shows that the higher the father's level of education the significant improvement in child's health and development outcomes.

Table 6: Result of one way analysis of variance of the influence of father's socio-economic status on child's heath and development.

\begin{tabular}{|c|c|c|c|c|c|}
\hline Variance sources & Sum of square (SS) & Degrees of freedom & Mean of square & F-Cal. & F-Crit. \\
\hline Between & 8.16 & 2 & 4.08 & & \\
\hline Within & 61.95 & 97 & 64 & 6.38 & 3.09 \\
\hline Total & 70.11 & 99 & & & \\
\hline
\end{tabular}

The result of one-way analysis of variance in Table 6 shows that there is significant influence of father's socio-economic status on child's heath and development. F $(2,97)=6.38, p=05$. The Least Significance difference (LSD) comparisons revealed that all the three means significantly different from others. High socio- 
economic status with the $(\mathrm{M}=3.06)$ than the mean of lower socio-economic status $(\mathrm{M}=2.56)$, and middle socioeconomic status $(\mathrm{M}=2.21)$. The result shows that the higher the father's socio-economic status the significant possible improvement in child's health and development outcomes.

\section{References}

[1]. Amato, P. R. (1998). More than money? Men's contributions to their children's lives Mahwah, NJ: Lawrence Erlbaum Associates, Publishers.

[2]. Amato, P. R., \& Booth, A. (1997). A generation at risk: Growing up in an era of family upheaval. Cambridge, MA: Harvard University Press.

[3]. Bowlby, J. (1982). Attachment and loss: Retrospect and prospect. American Journal of Orthopsychiatry 52, 664-678.

[4]. Biller H. B. (1981). Father absence, divorce, and personality development. New York: Wiley.

[5]. Biller, H. B. (19930. Fathers and families: Paternal factors in child development. Westport, Ct: Auborn House

[6]. Behrman, J., \& Taubman, P. (1985). Intergenerational earnings mobility in the United States: Some estimates and a test of Becker's intergenerational endowment model. Review of Economics and Statistics, 67, 144-151.

[7]. Bartlett E. (2004). The effects of fatherhood on the health of men: a review of the literature. Journal of Men's Health and Gender, $1: 159-169$.

[8]. Cabrear, N., Shannon, J. D, \& Tamis-LeMonda, C. (2007). Fathers' influence on their children's cognitive and emotional development: From Toddlers to Pre-K. Applied Developmental Science, 11, 08-213.

[9]. Currie J., \& Hyson R. (1999). Is the impact of health shocks cushioned by socioeconomic status? The case of low birth weight. American Economic Review, 89, 245-250.

[10]. Cairney, J., Boyle, M., Offord, D. R., \& Racine, Y. (2003). Stress, social support and depression in single and married mothers. Social Psychiatry and Psychiatric Epidemiology, 442-449.

[11]. Day, R. D., \& Lamb, M. E. (2000). Conceptualizing and measuring father involvement. Lawrence Erlbaum Associates.

[12]. Gjerdingen, D. K., Froberg, D. G., \& Fontaine, P. (1991). The effects of social support on women's health during pregnancy, labour, and delivery, and the postpartum period. Family Medicine, 23,370-375.

[13]. Gottfried, A. W., \& Bathurst, K. (1988). Maternal Employment, family environment, and child's development: Infancy through the school years. New York: Plenum.

[14]. Horn, W. F., \& Sylvester, T. (2002). Father Facts. National Fatherhood Initiative. Retrieved12/3/2013 from htt://www/fatherhood.org/fatherfacts.htm

[15]. Harnett, K. (2005). Children's elevated risk of asthma in unmarried families. Underlying structural and behavioral mechanisms Working Paper \#2005-01-FF. Princeton, NJ: Center for Research on Child Well-being. 19-27.

[16]. Lamb, M. E. (1997). Fathers and child development: An introductory overview and guide. New York: John Wiley \& Sons, Inc.

[17]. Lamb, M. E. (2000). Fatherhood in the twenty-first century. Child Development, 71,127-136.

[18]. Lewis, C. (1986). Becoming a father. Milton Keynes: Open University Press.

[19]. Luster, T., \& McAdoo, H. P. (1994). Factors related to the achievement and adjustment of young African-American children. Child Development, 65, 1080-1094.

[20]. McLandhan, S. (2003). The fragile families and child well-being study: Basline national report. Princeton, NJ: Center for research on Child Well-being :16

[21]. McLanahan, S., \& Sandefeur, G. D. (1994). Growing up with a single parent: What hurts, what helps. Cambridge, MA: Harvard University Press.

[22]. National Center for Education Statistics. (1997) Fathers' involvement in their children's schools. Washington, DC: U. S. Government Printing Office.

[23]. Nord, C. W., West, J. (2001). Father. And mothers' involvement in their children's schools. Washington, DC: U.S.

[24]. Nettles, M. T. Millett, C. T. (1999). The human capital liabilities of underrepresented minorities in pursuit of science, mathematics and engineering doctoral degrees. Research News on Minority Graduate Education.

[25]. O’Connor, T., Davies, L., Dunn, J., \& Golding, J. (2000). Differential distribution of children's accidents, injuries, and illnesses across family type. Pediatrics, 106.

[26]. Purcell-Gates, V. (1996)., Stories, Coupons, and the "TV Guide": Relationships between Home Literacy Experiences and Emergent Literacy Knowledge. Reading research Quarterly, 31, 406-28.

[27]. Pedersen, F. A., Anderson, B. J., \& Kain, R. L. (1980). Parent-infant and husband wife interactions observed at age five months New York: Praeger.

[28]. Pleck, J. H., \& Masciadrelli, B. P. (2004). Paternal involvement by U. S. residential fathers. New York: John Willey.

[29]. Public Health Agency of Canada. (2003). Determinants of health. Retrieved: 08/03/2013, from www.phacaspc.ca/phsp/phdd/determinants

[30]. Radin, N. (1982). Primary care giving and role sharing fathers. Non-traditional families: Parenting and child development (pp. 173204). Hillsdale, NJ: Erlbaum.

[31]. Thompson, S. J., Auslander, W. F., White, N. H. (2001) Influence of family structure on health among youths with diabetes. Health and social work, 26, (1).

[32]. Teitler, J. O. (2001). Father involvement, child health, and maternal health behavior. Children and Youth Services review, 23 $(4 / 5), 403-425$.

[33]. UN (2003), World Development Report 2003, United Nations, New York.

[34]. US Department of Health and Human Services. (1995). Public Health Service Center for Disease Control and Prevention. National Center for Health Statistics. Report to Congress on Out-of-Wedlock Childbearing. Hyattsville, MD.

[35]. Wolfe, B., Zuvekas, S., (1997). Nonmarket Outcomes of Schooling. International Journal of Educational Research, $27,491-501$.

[36]. Zick, C.D., \& Allen, C. R. (1996). The impact of parents' marital status on the time adolescents spend in productive activities. Family Relations, 45,65-71.

[37]. Zvara, B. J (2009) Can fathers' education level moderate relations between low birth weight and child cognitive development outcomes? Unpublished Masters Thesis. Ohio State University. 